\title{
An integrated model of production and inventory cycles of new and reusable bottling packages in a closed supply chain
}

\section{Conference Paper · April 2016}

\section{CITATIONS}

0

3 authors:

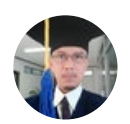

Jonrinaldi Jonrinaldi

Universitas Andalas

29 PUBLICATIONS 86 CITATIONS

SEE PROFILE

\section{David Zhang}

University of Exeter

81 PUBLICATIONS 2,232 CITATIONS

SEE PROFILE
READS

26

\section{Taufiq Rahman}

Akademi Telekomunikasi Nusantara

7 PUBLICATIONS O CITATIONS

SEE PROFILE

Some of the authors of this publication are also working on these related projects:

Project
AN INTEGRATED PRODUCTION AND INVENTORY MODEL OF NEW AND REUSABLE BOTTLING PACKAGES IN A CLOSED SUPPLY CHAIN View project

A MODIFIED ECONOMIC PRODUCTION QUANTITY (EPQ) FOR MULTIPLE ITEMS WITH SYNCHRONIZING DISCRETE AND CONTINUOUS DEMAND SIMULTANEOUSLY View project 
Malaysia Institute of Transport (MITRANS) Logistics and Transport International Conference 2016, MILTC2016, 12-14 April 2016, Universitas Andalas, Padang, Indonesia

\title{
An integrated model of production and inventory cycles of new and reusable bottling packages in a closed supply chain
}

\author{
Jonrinaldi ${ }^{\mathrm{a} *}$, Taufiq Rahman ${ }^{\mathrm{a}}$, David Z. Zhang ${ }^{\mathrm{b}}$ \\ ${ }^{a}$ Department of Industrial Engineering, Andalas University, Padang, Indonesia, 25163 \\ ${ }^{b}$ Exeter Manufacturing Enterprise Centre (XMEC), College of Engineering, Mathematics and Physical Sciences, \\ University of Exeter, Exeter, EX4 4QF, United Kingdom
}

\begin{abstract}
This paper proposes a model and solution for integrated production and inventory of new and reusable bottling packages. The inventory which didn't match the production needs is caused by the difference of production policy and the reverse logistics policy from distribution center. In addition, this problem is also influenced by cleanliness level of the bottles and the reject bottles during transportation. The solution of this model uses enumeration approach and simultaneous approach (using software LINGO 14.0). From the calculation, this model obtains a valid result. The company can reduce the inventory cost about $8.88 \%$ using enumeration approach and 8.84\% using simultaneous approach. Also, this model isn't sensitive in terms of changes of parameter to optimum solution.

(C) 2016 The Authors. Published by Elsevier Ltd.

Peer-review under responsibility of the Universiti Teknologi MARA Sarawak.
\end{abstract}

Keywords: reverse logistics, integrated inventory model, bottling packages, inventory cost, closed supply chain

\section{Introduction}

Industrial activities in Indonesia are growing faster annually. The growth of these industrial activities can be seen from the value of Gross Domestic Product (GDP) in manufacturing industry sector. The growth of manufacturing industry sectors are increase 4.5\% in 2010 [1], $6.2 \%$ in 2011 [2], $5.73 \%$ in 2012 [3], and $5.56 \%$ in 2013 [4]. The growth of these activities had positive impact for Indonesian economics which provide jobs for citizens. Even so, this growth also had negative impact. The negative impact is increasing the environmental pollution that caused by garbage or industrial waste. One of the government's policies to overcome the negative impact of industrial activities is to establish an act, which is The Republic of Indonesia act Number 18 of 2008 about waste management. The Republic of Indonesia act Number 18 of 2008 said that "Producer must be manage their package and/or product that cannot or hard to decomposing by nature process" [6]. This act make producer to use reverse

\footnotetext{
* Corresponding author. Tel.: +62-751-72497; fax: +62-751-72566.

E-mail address: jonrinaldi@ft.unand.ac.id.
} 
logistics in their supply chain management. So that they can manage their packages or products. Otherwise, the act is not only factors that making producer to use reverse logistics. The other factors are economically benefits of using the return product and public environmental awareness [5].

Generally glass bottle used for beverages drink production. This bottles can use for several times. So that reverse logistics concept can be applied. The common problem is to manage the glass bottles inventory. Thus, inventory didn't match the production needs. This problem is caused by the difference of production policy and the reverse logistics policy from distribution center. In addition, this problem is also influenced by cleanliness level of the bottles and the reject bottles during transportation. This research is performed to improve an integrated production and inventory model for glass bottles which minimize the inventory costs.

\section{Mathematical Model}

The mathemetical model was create from the characteristic system. The Characteristic systems including warehouse, shop floor, distribution center, and SL (Sub Location) and MTP (Manage Third Party). The product will be held in the product warehouse for 3 days before it transfer to distribution center. The packaging bottles made from glass, so it is easy to break during production and sometime it is break during transportation too. Therefore, there will be new bottles to replace the broken ones. Fig 1 below show the distribution flow of reusable bottles, new bottles, and product of the company.

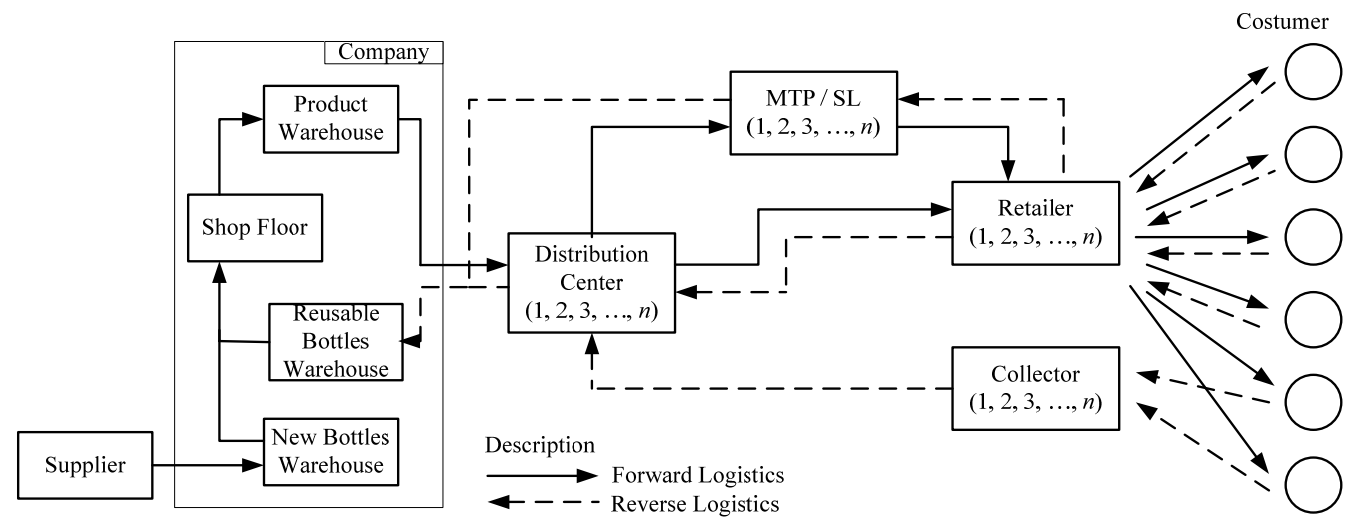

Fig. 1 Distribution Flow of Reusable Bottles, New Bottles, and Product.

Based on the characteristics system, it can be used to make inventory behavior of this system. This inventory behavior shows integrated production and inventory bottle cycles. Fig. 2 below shows the inventory behaviors of Reusable Bottles, New Bottles and Product. 


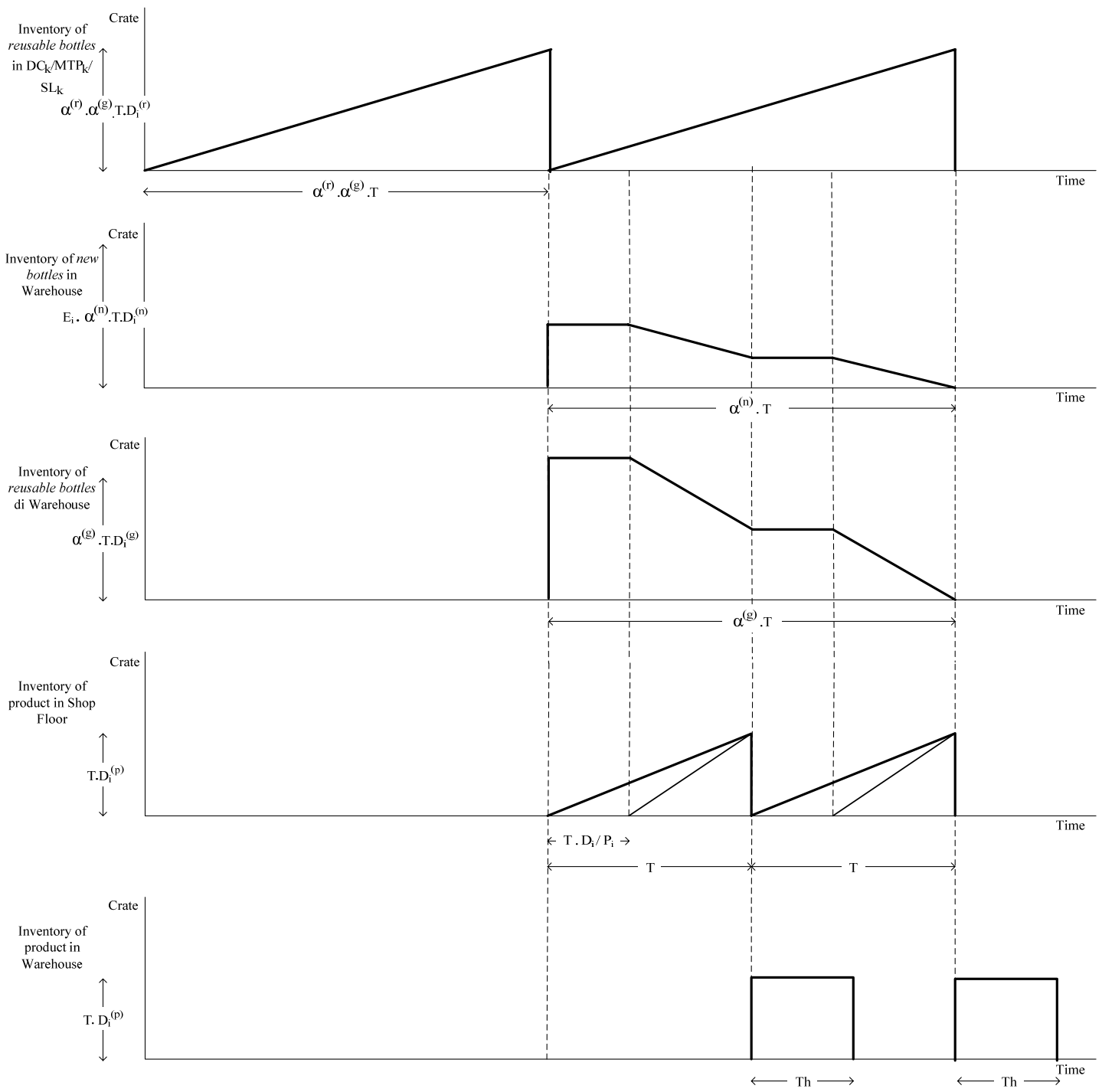

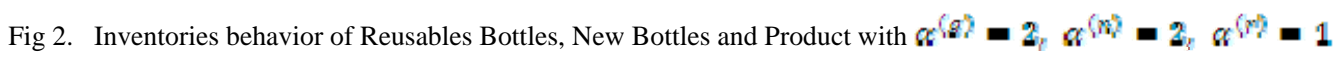


The mathematical model is develop by using the concept of inventory model by tersine [9] and waters [10] and inventory model research by taunter [8] and jonrinaldi [7].

\subsection{Notations}

Notations that be used later consists of input parameters and decision variables. The notations are as listed comprehensively in Appendix A.

\subsection{Cost Components in Shop Floor}

The cost that calculate in shop floor are production cost, setup cost and holding cost. The total cost for shop floor, $T \mathrm{C}_{t}^{(8)}$, is given by

$$
\begin{aligned}
& \tau C_{i}^{(p)}=\left(D_{i}^{(p)} \times P_{i}\right)+\frac{S_{i}^{(p)}}{T_{i}}
\end{aligned}
$$

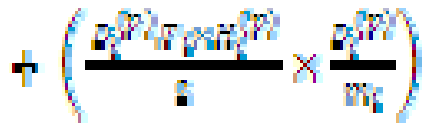

By setting

$$
\begin{aligned}
& \frac{\sigma \sigma^{2}}{\partial \tau}=0 \text {, then }
\end{aligned}
$$

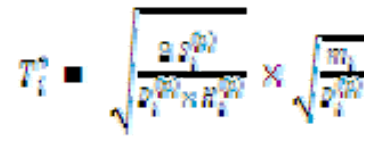

\subsection{Cost Components in Product Warehouse}

The cost that calculate in product warehouse are setup cost and holding cost. The total cost for product warehouse, $T \mathcal{G}_{t}^{\left(m_{i}\right)}$, is given by

$$
T C_{t}^{(h)}=\frac{s^{(h)}}{T_{t}}+\left(D_{t}^{(B)} \times H_{t}^{(h)} \times T_{i}\right)
$$

In this product warehouse, there is a time for holding the product before it is deliver to distribution center. The time for holding product, $T_{h}$, is 3 days. The second term above is holding cost of product.

\subsection{Cost Components of Reusable Bottles in Warehouse}

The cost that calculate for reusable bottles in warehouse are order cost and holding cost. The total cost for reusable bottles in warehouse $g, T G_{t}^{(g)}$, is given by 


$$
\begin{aligned}
& T C_{t}^{(g)}=\frac{\sum_{t}^{2} A_{t}^{(g)}}{\alpha_{t}^{G} \cdot T_{t}}
\end{aligned}
$$

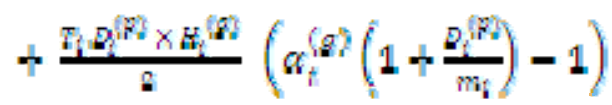

The second term is holding cost for reusable bottles in warehouse. In this term, product can be use for one or several time of production. The concept in this term can be seen in this fig below.
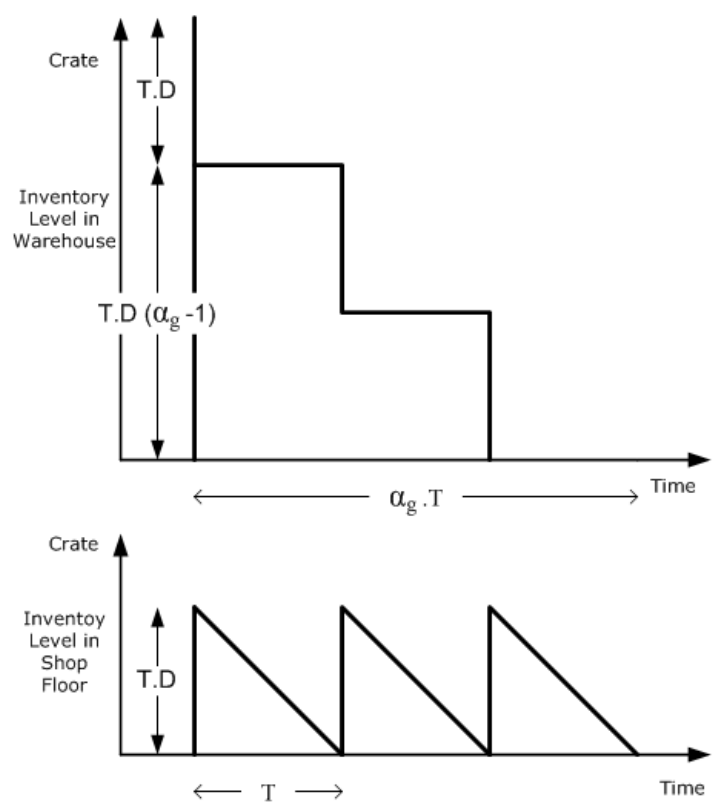

Fig 3. Inventories Behaviour in Warehouse and Shop Floor with $\alpha_{\mathrm{g}}=2$

\subsection{Cost Components of New Bottles in Warehouse}

The cost that calculate for new bottles in warehouse are purchase cost, order cost and holding cost. Holding cost for new bottles has the same concept with holdng cost for reusable bottles in warehouse. The total cost for reusable bottles in warehouse $T \mathrm{C}_{t}^{(n)}$, is given by

$\pi \Theta_{i}^{n}-\left(E_{i}, D_{i}^{(2)} \times E_{i}^{(n)}\right)+\frac{A_{i}^{(n)}}{\sigma_{i}^{n}, T_{i}}$ 


$$
+\left(\frac{\pi_{1} E_{i} E^{m} \times E^{(n t}}{2}\left(\alpha_{t}^{(n)}\left(1+\frac{E_{1} \theta^{m}}{m_{i}}\right)-1\right)\right)
$$

3.6 Cost Components of Reusable Bottles in DC/MTP/SL

The cost that calculate for reusable bottles in DC/MTP/SL are purchase cost, order cost, transportasion cost and holding cost. The total cost for reusable bottles in DC/MTP/SL $T C_{i}$, is given by

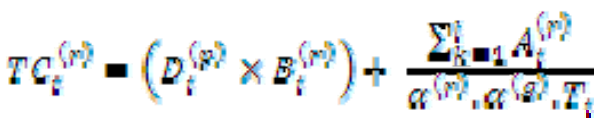

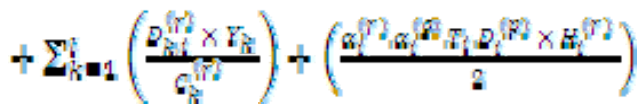

The second term is order cost for reusable bottles. This cost is total of order cost for all retailer. Beside that, The third term is transportastion cost for reusable bottles from DC/MTP/SL to warehouse. This cost is total of transportasion cost from all DC/MTP/SL.

\subsection{Disposal Cost}

Disposal cost is cost that use to extinguish the damage products or transportation cost to other company for recycle the damage products. The disposal cost for damage bottles $T C_{i}$, is given by

$$
T C_{t}^{(n)}=E_{t, 1} D_{t}^{(B)}, T_{t} \times V
$$

The percentage of damage product, $E_{i}$, is cumulative of damage product percentage in production process and damage reusable bottles percentage in transportation.

\subsection{Washing Cost of Not Ready Bottles}

The reusable bottles in warehouse is divide into two categories, ready bottles and not ready bottles. The ready bottles can be use to production without washing it in manual way. Contrary to the not ready bottles, this bottles must be washing in manual way first, before it is use to production. The washing cost for not ready bottles, $T C_{t}$, is given by

$T C_{t}^{(w)}=W_{i}, \alpha_{t}^{(Q)}, D_{t}^{(\theta)}, T_{i} \times 0$

3.9 Total Cost For Each Product

Glass bottles that being used for production is different for each product. So, the total cost for each product is given by

$$
\begin{gathered}
T C_{t}^{(2)}=T C_{t}^{(\beta)}+T C_{t}^{(n)}+T C_{t}^{(g)}+T C_{t}^{\left(m^{2}\right)} \\
+T C_{t}^{(n)}+T C_{t}^{(\omega)}+T C_{t}^{(w)}
\end{gathered}
$$




\subsection{Total Cost For All Product}

Total cost for all product is cumulative cost for each type product. The total cost is given by

$$
T C=\sum_{i=1}^{Z} T C_{t}^{(d)}
$$

\subsection{The Solution Methods}

Mathematical model that was create in this reasearch can be solved by using two methods, enumeration method and stimultanious approach.

\subsubsection{Enumeration Method}

Enumeration method is used to solve the model by steps. In this method, shop floor system is assuming to be independent to the other systems. So, the optimal production that be used in this formula gained from shop foor system.

The complete solution method is as follows :

Step 1: $\quad$ Determine the optimal production cycle time, $T_{i}^{*}$ base on Eq (2).

Step 2: $\quad$ The optimal production cycle time is subsitution to Eq (1) to obtain total cost in Job Floor.

Step 3: The optimal production cycle time is subsitution to Eq (3) to obtain total cost in Product Warehouse.

Step 4: The optimal production cycle time is subsitution to Eq (4) to obtain total cost of reusable bottles in Warehouse, Since the value of $x^{2}$ is small, the optimal value can be obtain with

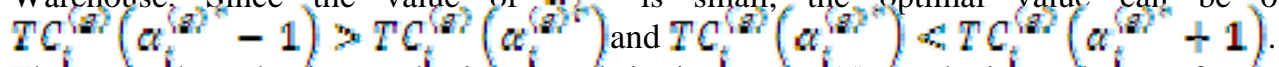

Step 5: The optimál production cycle time is subsitution to Eq(5) to obtain total cost of new bottles in Warehouse Since the value of $\mathscr{G}^{\text {nin }}$ is small, the optimal value can be obtain

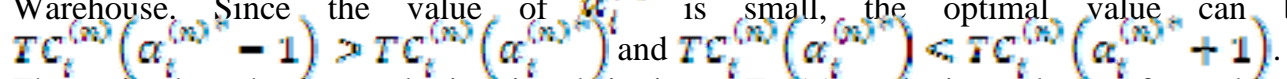

Step 6: The optimal production cycle time is subsitution to Eq (6) to obtain total cost of reusable bottles in DC/MTP/SL Since the value of $x^{2}$ is small the optimal value can be obtain with

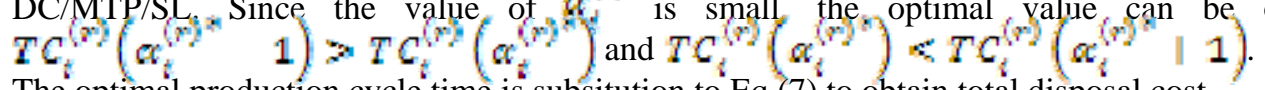

Step 7: The optimal production cycle time is subsitution to $\mathrm{Eq}(7)$ to obtain total disposal cost.

Step 8: $\quad$ The optimal production cycle time is subsitution to Eq (8) to obtain total washing cost.

Step 9: $\quad$ The cost that obtain from step 2 to step 8 is subsitution to Eq (9) to obtain total cost of one product.

Step 10: $\quad$ Repeat step 1 to step 9 for all type products.

Step 11: The cost that obtain from step 9 and step 10 is subsitution to Eq (10) to obtain total cost for all product.

\subsubsection{Stimultanious Approach}

Stimultaneous approach is used to solve the model by searching the decision variables at the same time. This model can be solve by using the mix integer non linear programming. Therefore, this reasearch is use a software that called LINGO 14.0. The complete model for total cost can be states as follows :

$$
\begin{gathered}
\operatorname{Mn} T C_{t}^{(b)}=T C_{t}^{(p)}+T C_{t}^{(h)}+T C_{t}^{(Q)}+T C_{t}^{(n)}+T C_{t}^{(n)} \\
+T C_{t}^{(n)}+T C_{t}^{(\phi)}
\end{gathered}
$$

s/t.

$$
\begin{aligned}
& T_{t}>0 \\
& \alpha_{t}^{(\theta)}, \alpha_{t}^{(m)}, \alpha_{t}^{(m)}=1
\end{aligned}
$$




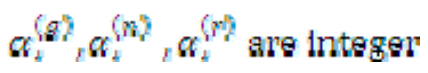

\section{Numerical Example}

Numerical example is presented to illustrate the system which will be solved by this model developed. This example is used the real company data that use 7 type of product. Table 1 below shows the input data for model.

Table 1. Input Data for The Model

\begin{tabular}{|c|c|c|c|c|c|c|c|c|c|}
\hline Input & & $i=1$ & $i=2$ & $i=3$ & $i=4$ & $i=5$ & $i=6$ & $i=7$ & \\
\hline$m_{i}$ & & $1,199,250$ & $1,199,250$ & $1,199,250$ & $1,199,250$ & $1,199,250$ & $1,199,250$ & $1,199,250$ & Crate / Year \\
\hline$D_{i}^{(p)}$ & & 408,250 & 103,066 & 68,127 & 75,099 & 96,832 & 31,357 & 12,747 & Crate / Year \\
\hline$E_{i}$ & & 0.369 & 0.353 & 0.353 & 0.360 & 0.360 & 0.366 & 0.366 & \\
\hline$w_{i}$ & & 0.056 & 0.137 & 0.264 & 0.052 & 0.290 & 0.070 & 0.147 & \\
\hline$T_{h}$ & & 0.0082 & 0.0082 & 0.0082 & 0.0082 & 0.0082 & 0.0082 & 0.0082 & / Year \\
\hline$B_{i}^{(n)}$ & IDR & 12,000 & 10,800 & 14,400 & 10,800 & 14,400 & 10,800 & 14,400 & / Crate \\
\hline$B_{i}^{(r)}$ & IDR & 12,000 & 10,800 & 14,400 & 10,800 & 14,400 & 10,800 & 14,400 & / Crate \\
\hline$P_{i}$ & IDR & 18,000 & 16,800 & 24,000 & 16,800 & 24,000 & 16,800 & 24,000 & / Crate \\
\hline$S_{i}^{(p)}$ & IDR & 85,000 & 85,000 & 85,000 & 85,000 & 85,000 & 85,000 & 85,000 & / Setup \\
\hline$s_{i}^{(h)}$ & IDR & 8,000 & 8,000 & 8,000 & 8,000 & 8,000 & 8,000 & 8,000 & / Setup \\
\hline$H_{i}^{(n)}$ & IDR & 2,400 & 2,160 & 2,880 & 2,160 & 2,880 & 2,160 & 2,880 & / Crate. Year \\
\hline$H_{i}^{(\gamma)}$ & IDR & 2,400 & 2,160 & 2,880 & 2,160 & 2,880 & 2,160 & 2,880 & / Crate. Year \\
\hline$H_{i}^{(g)}$ & IDR & 2,400 & 2,160 & 2,880 & 2,160 & 2,880 & 2,160 & 2,880 & / Crate. Year \\
\hline$H_{i}^{(h)}$ & IDR & 9,600 & 9,600 & 12,000 & 9,600 & 12,000 & 9,600 & 12,000 & / Crate. Year \\
\hline$H_{i}^{(p)}$ & IDR & 9,600 & 9,600 & 12,000 & 9,600 & 12,000 & 9,600 & 12,000 & / Crate. Year \\
\hline$A_{i}^{(g)}$ & IDR & 150,000 & 150,000 & 150,000 & 150,000 & 150,000 & 150,000 & 150,000 & / Order \\
\hline$A_{i}^{(n)}$ & IDR & 7,650 & 7,650 & 7,650 & 7,650 & 7,650 & 7,650 & 7,650 & / Order \\
\hline$A_{i}^{(r)}$ & IDR & 300,000 & 300,000 & 300,000 & 300,000 & 300,000 & 300,000 & 300,000 & / Order \\
\hline $\begin{array}{l}V \\
0\end{array}$ & $\begin{array}{l}\text { IDR } \\
\text { IDR }\end{array}$ & $\begin{array}{l}1,440 \\
1,920\end{array}$ & $\begin{array}{l}1,440 \\
1,920\end{array}$ & $\begin{array}{l}1,440 \\
1,920\end{array}$ & $\begin{array}{l}1,440 \\
1,920\end{array}$ & $\begin{array}{l}1,440 \\
1,920\end{array}$ & $\begin{array}{l}1,440 \\
1,920\end{array}$ & $\begin{array}{l}1,440 \\
1,920\end{array}$ & $\begin{array}{l}\text { / Crate. Year } \\
\text { / Crate. Year }\end{array}$ \\
\hline$\sum_{k=1}^{l}\left(\frac{D_{k i}^{(r)} \times \gamma_{k}}{C_{k}^{(r)}}\right)$ & IDR & $357,850,000$ & $92,650,000$ & $67,150,000$ & $70,550,000$ & $90,950,000$ & $32,300,000$ & $17,850,000$ & / Year \\
\hline
\end{tabular}

Based on data above, the model can be solved with enumeration method and simultaneous approach. With enumeration method, computational method is used step by step. The optimal production time of this model is got by using Eq. 2. This time is used to the other equations. The inventory total cost got from computational is IDR 29,326,767,613 per year. With using software LINGO 14.0 for simultaneous approach, the inventory total cost is IDR 29,339,774,100 per year. Table 2 below shows the result of model by using enumeration method.

Table 2. The Computational Result with Enumeration Method 


\begin{tabular}{|c|c|c|c|c|c|c|c|c|c|}
\hline $\begin{array}{c}\text { Decision } \\
\text { variables }\end{array}$ & & $i=1$ & $i=2$ & $i=3$ & $i=4$ & $i=5$ & $i=6$ & $i=7$ & \\
\hline$T_{i}^{*}$ & & 0.0113 & 0.0447 & 0.0605 & 0.0614 & 0.0426 & 0.1470 & 0.3234 & / Year \\
\hline$\alpha_{i}^{(g)^{*}}$ & & 1 & 1 & 1 & 1 & 1 & 1 & 1 & \\
\hline$\alpha_{i}^{(n)^{*}}$ & & 2 & 2 & 2 & 2 & 2 & 2 & 2 & \\
\hline$\alpha_{i}^{(r)^{*}}$ & & 2 & 1 & 1 & 1 & 1 & 1 & 1 & \\
\hline$T C_{i}^{(p)}$ & IDR & $7,363,560,223$ & $1,735,310,875$ & $1,637,857,826$ & $1,264,433,580$ & $2,327,961,734$ & $527,954,351$ & $306,453,737$ & / Year \\
\hline$T C_{i}^{(h)}$ & IDR & $32,921,319$ & $8,311,252$ & $6,851,602$ & $6,055,991$ & $9,738,494$ & $2,528,631$ & $1,281,979$ & / Year \\
\hline$T C_{i}^{(g)}$ & IDR & $1,884,221$ & 434,440 & 346,254 & 320,872 & 485,633 & 152,179 & 111,592 & / Year \\
\hline$T C_{i}^{(n)}$ & IDR & $1,808,582,509$ & $393,120,964$ & $346,450,419$ & $292,128,030$ & $502,191,168$ & $124,008,841$ & $67,210,520$ & / Year \\
\hline$T C_{i}^{(r)}$ & IDR & $5,281,198,428$ & $1,217,449,341$ & $1,059,072,734$ & $891,485,104$ & $1,498,313,982$ & $377,973,922$ & $208,269,987$ & / Year \\
\hline$T C_{i}^{(v)}$ & IDR & $2,448,683$ & $2,342,507$ & $2,095,202$ & $2,388,959$ & $2,136,750$ & $2,428,775$ & $2,172,362$ & / Year \\
\hline$T C_{i}^{(0)}$ & IDR & 496,826 & $1,210,855$ & $2,092,314$ & 458,934 & $2,298,944$ & 623,600 & $1,160,166$ & / Year \\
\hline$T C_{i}^{(s)}$ & IDR & $14,491,092,209$ & $3,358,180,235$ & $3,054,766,352$ & $2,457,271,470$ & $4,343,126,705$ & $1,035,670,300$ & $586,660,342$ & / Year \\
\hline$T C$ & IDR & & & & $9,326,767,613$ & & & & / Year \\
\hline
\end{tabular}

\section{Conclusion}

The mathematical model that was created can be solved the inventory problem. By synchronized the production and inventory system, it can reduce the total inventory cost. The current total inventory cost is IDR 32.185.637.113 per year. With using the enumeration method, it can reduce the current inventory cost by $8.84 \%$. Otherwise, with using simultaneous approach, the total inventory cost can be reduced to $8.88 \%$ from the current total inventory cost. Although, the total inventory cost that get

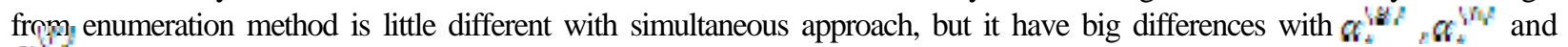
$U_{i}$ policy. Table 3 below shows the comparison of enumeration method, simultaneous approach and the current company policy.

\section{Acknowledgements}

Jonrinaldi thanks the Andalas University with the grant No.039/UN16/PL/AKS/2015.

\section{References}

Badan Pusat Statistik. (2011). Pertumbuhan Ekonomi Indonesia. Berita Resmi Statistik, XIV/ No. 12/02/Th, 1-7.

Badan Pusat Statistik. (2012). Pertumbuhan Ekonomi Indonesia. Berita Resmi Statistik, XV/ No. 13/02/Th, 1-8.

Badan Pusat Statistik. (2013). Pertumbuhan Ekonomi Indonesia. Berita Resmi Statistik, XVI/ No. 14/02/Th, 1-9.

Badan Pusat Statistik. (2014). Pertumbuhan Ekonomi Indonesia. Berita Resmi Statistik, XVII/ No. 16/02/Th, 1-9.

Daher, C. E dkk. (2006). Reverse Logistics: Opportunity to Reduce Cost by ntegrated Value Chain Management. Brazilian Business Review. 3 (1), 57-72. Vitoria-ES, Brazil.

Indonesia. (2008). Undang-Undang Republik Indonesia Tentang Pengelolaan Sampah. 2008/ 18.

Jonrinaldi dan Zhang D. Z. (2013). An Integrated Production and Inventory Model for A Whole Manufacturing Supply Chain Involving Reverse Logistics with Finite Horizon Period. Omega. 41, 598-620. Elsevier Ltd.

Taunter, R. H., (2001). Economic Ordering Quantities for Recoverable Item nventory Systems. Naval Research Logistics. 48, 484-495. John Wiley \& Sons, Inc.

Tersine, R. J. (1994). Principles of Inventory and Materials Management, 4th edition. PTR Prentice-Hall, Inc. New Jersey.

Waters, D. (2003). Inventory Control and Management. John Wiley \& Sons Ltd. England 